\title{
The Practical Philosophy of Al-Fārābī and Avicenna: A Comparison*
}

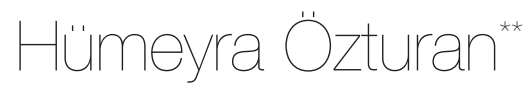

\begin{abstract}
This article compares the approaches to practical philosophy of the two most significant Muslim philosophers of the classical period, al-Fārābī (d. 950) and Ibn Sīnā (d. 1037). Initially, I will examine their classification of the practical sciences and show their formal differences, and then question whether these differences point to a fundamental disagreement about the source of practical knowledge. One of my conclusions is that al-Fārābī clearly separated the intellectual and independent concept of practical philosophy from the religious sciences, whereas Ibn Sinnä's standpoint is religious-based, dependent, and partially covered by Islamic jurisprudence. As the latter emphasizes these various points in separate passages about the source of practical knowledge, a holistic and illustrative combination of these passages is required. Thus, by citing and discussing all of these passages, I suggest that Ibn Sinnā not only accepted the prophetic legislation of the practical sciences, but also provided an epistemological background that makes it possible to take account of the earlier Greek and Muslim moral philosophers' legacy. Finally, I also point out that the main reason for these philosophers' differences over practical philosophy is their disagreement about the relation between religion and philosophy.
\end{abstract}

Keywords: Al-Fārābī, Ibn Sīnā/Avicenna, ethics, morality, moral philosophy, al-hikmat al-'amaliyya, classification of practical sciences.

\footnotetext{
* I sincerely thank M. Cüneyt Kaya and the anonymous reviewers whose suggestions significantly improved this article.

** Assist. Prof., Marmara University, Faculty of Theology, Department of History of Philosophy. Correspondence: humeyrakaragozoglu@gmail.com.
} 

significant philosophers of the classical period of Islamic philosophy (eighth-thirteenth centuries), constructed their consistent philosophical systems in such a way that they encompass almost all of the philosophical disciplines, from ontology to ethics. Although al-Fārābī centered more of his philosophy on moral philosophy and Avicenna wrote mostly about logic and metaphysics, one can follow their main ideas about ethics, household management, and politics. A large number of independent publications deal with al-Fārābī's ${ }^{1}$ and Avicenna's ${ }^{2}$ view of practical philosophy, the majority of which concentrates on describing and analyzing the former's ethics and politics or questioning the possible reasons for the latter's disinterest in practical philosophy. However, the few works that focus on comparing their practical philosophy are so superficial that they either describe these ideas in a very general way ${ }^{3}$ or compare them in the frame of only one concept or problem. ${ }^{4}$ Also, some of these works - especially some studies on Avicenna -

1 These are the some sources for al-Fārābī's approach to practical philosophy: Miriam Galston, Politics and Excellence: The Political Philosophy of Alfarabi (New Jersey: Princeton University Press, 1990); Thérèse-Anne Druart, "Al-Fārābī on the Practical and Speculative Aspects of Ethics," Moral and Political Philosophies in the Middle Ages, ed. B. Carlos Bazan et al. (Ottova: Legas, 1995): 476-85; Thérèse-Anne Druart, "Al-Fārābī, Ethics and First Intelligibles," Documents Etudi Sulla Tradizione Filozofica Medieval, VIII (1997): 403-23; Yaşar Aydınlı, Fârâbî'de Tanrı-İnsan İlişkisi (İstanbul: İz Yayıncıllk, 2000); Mehmet Aydın, “Fârâbî’de Pratik Akıl Yürütme,” D. E. Ü. İlahiyat Fakültesi Dergisi, 21 (İzmir, 2005): 149-74; Fatih Toktaş, Fârâbî'de Ahlâk ve Siyaset (Samsun: Etüt Yayınları, 2009); Muhsin S. Mahdi, Alfarabi and the Foundation of Islamic Political Philosophy (Chicago: The University of Chicago Press, 2010); Hümeyra Özturan, Akıl ve Ahlâk: Aristoteles ve Fârâbîde Ahlakın Kaynağı (İstanbul: Klasik Yayınları, 2014).

2 Some of the leading works on Avicenna's practical philosophy are A. Nevzat Ayas, "İbn Sînâ'nın Filozofik Sisteminde Ahlâk," Büyük Türk Filozofu ve Tıb Üstadı İbni Sinnā Şahsiyeti ve Eserleri Hakkında Tetkikler (İstanbul, 1937): 1-11; Muhsin Mahdi, “Avicenna: Practical Science,” Encyclopedia Iranica, III, ed. Ehsan Yarshater (London, 1989): 84-88; James W. Morris, “The Philosopher-Prophet in Avicenna's Political Philosophy," The Political Aspects of Islamic Philosophy, ed. Charles E. Butterworth (Cambridge, 1992): 153-98; Charles E. Butterworth, “The Political Teaching of Avicenna," Topoi 19 (2000): 35-44; Ali Abbas Murad, Davla al-sharīa: Qırāa fĩ jadaliyya al-dīn wa al-siyāsa 'inda Ibn Sīnā (Beirut, 1999); M. Cüneyt Kaya, "Peygamberin Yasa Koyuculuğu: İbn Sinâ'nın Amelî Felsefe Tasavvuruna Bir Giriş Denemesi," Dîvân: Disiplinlerarası Çalışmalar Dergisi 27 (2009): 57-91; Müfit Selim Saruhan, "İbn Sînâ'da Ahlâkî Çözüm Üzerine,” Uluslararası İbn Sînâ Sempozyumu Bildirileri, ed. M. Mazak, N. Özkaya (İstanbul: İstanbul Büyükşehir Belediyesi Kültür A.Ş, 2009).

3 The most representative example of this is Charles E. Butterworth, "Ethics in Medieval Islamic Philosophy" (The Journal of Religious Ethics, 11/2 (1983): 224-239). At the beginning, Butterworth states that he would compare al-Fārābī, Avicenna and Averroes' approaches to practical philosophy. But instead, he summarizes the three philosophers' ethical and political ideas separately and in a completely general way. Because of this, this article might be considered only as an introductive study. Hajj Muhammad Legenhausen's article "Ibn Sina's Practical Philosophy" (Religious Inquiries II/3 (2013): 5-27) also aims to compare Avicenna and al-Fārābīs practical philosophy but it is also significantly superficial.

4 These might be indicated as examples of this kind of studies: M. E. Marmura, "Al-Ghazali on Ethical Premises,” The Philosophical Forum 1, no. 3 (1969): 393-403; Jules L. Janssens, “Experience’ (tajriba) 
provide an incorrect and inaccurate opinion of the two philosopher's practical philosophy, as they ignore all of their books and the different passages that appear in separate books. ${ }^{5}$

Given these deficiencies in the literature, this essay seeks to compare al-Fārābī and Avicenna's practical philosophy in order to investigate their similar and different points. Initially, as opposed to the present studies, this comparison is designed to illustrate their complete practical approach by pointing out and analyzing how they classified the practical sciences. Second, those differences will be investigated to determine whether they depend on a radical disagreement about the origin of practical knowledge. In this manner, I hope to provide a comparison that is both complete and broad, as well as deep and focused, that will go some way to presenting a better understanding of al-Fārābī and Avicenna's practical philosophy.

Especially for Avicenna, whose writings on this subject are narrower and separated in different books, it seems quite important to acquire a whole and consistent understanding of his approach. Moreover, the numerous interpretations of his practical philosophy have affected the ideas about his reaction to alFārābī's practical approach. Thus, to achieve my stated goal, I analyzed all of his contradictory passages in an attempt to clarify his approach and, accordingly, get an idea about the accuracy of the different interpretations of Avicenna's practical philosophy found in the literature.

in Classical Arabic Philosophy (al-Farabi-Avicenna)," Quaestio 4 (2004): 45-62; Maftouni Nadia, Noori Mahmoud, "A Comparative Study on Farabi and Avicenna's Viewpoints about the Ultimate Goal of Art and the Role of Entertainment, Wonder and Pleasure," Avicinian Philosophy Journal 22, no. 59 (Tehran, 2018): 27-40; Bakhshi Mansureh, Sadeghi Hasanabadi Majid, Emamijome Mehdi, "Place of Woman in Social System and Family from the Point of View of Farabi, Avicenna and Khadej Nasir," Avicinian Philosophy Journal 22, no. 59 (Tehran, 2018): 5-25.

Miriam Galston's “Realism and Idealism in Avicenna's Political Philosophy” (The Review of Politics 40, no. 4 [October 1979]: 561-77) and Deborah L. Black's "Practical Wisdom, Moral Virtue and Theoretical Knowledge: The Problem of the Autonomy of the Practical Realm in Arabic Philosophy" (Moral and Political Philosophies in the Middle Ages, ed. B. Carlos Bazan et al. [Ottova: Legas, 1995]): 451-65) present more comprehensive comparisons than the articles mentioned above. However, Galston's comparison is mostly within the framework of politics and does not seek to interpret the two philosophers' approaches to practical philosophy as a whole. Black's article includes a comparison that is centered on practical philosophy's theoretical underpinnings and deals with some issues that I will analyze in this article. I will also try to indicate those points that she disregards.

5 Charles Butterworth's article "Medieval Islamic Philosophy and the Virtues of Ethics" (Arabica 34 [1987]): 221-50) is a typical example of this. Focused on al-Fārābī and Avicenna's ethics, it compares them within the framework of the limits of practical philosophy as well as the function of the theoretical and practical intellects. The most crucial problem in this article is that Butterworth almost never mentions religion's function as a source of morality, which Avicenna clearly points out, but focuses only the understanding of ethics in terms of the theoretical and practical intellect. Given his non-indication of religion's relation to the practical field in Avicenna's thinking, the article's conception of this philosopher is deficient. 
Al-Fārābī clearly emphasizes practical knowledge's intellectual origin, whereas Avicenna's contradictory passages indicate either the intellect or religion as the source of practical knowledge. My argument is even though al-Fārābī's practical philosophy is completely independent, Avicenna's is partly covered by fiqh (Islamic jurisprudence) and thus religion, at least in his practical approach, has a determinative authority on the practical field. Furthermore, I claim that Avicenna has also built an epistemological background that enables one to benefit from the earlier (Greek and Islamic) philosophical legacy. Herewith, he could speak about both divine determination and the function of primary (awwalī), generally accepted (mashhūr), widespread (zẩi) and experimental (tajrībī) premises in practical field. Accordingly, even though divine determination makes it impossible to speak about an independent practical philosophy for Avicenna, one can still benefit from the knowledge of an independent practical philosophy. In contrast to Avicenna's perspective, which combines fiqh and philosophy, al-Fārābī avoided exactly from this approach and he separated fiqh and kalām from philosophical ethics and politics; he substantiated ethics independently from religion. The ground of their disagreement undoubtedly lies in how they understand the religion-philosophy relationship - al-Fārābī claims that philosophy came before religion, whereas Avicenna makes philosophy dependent on religion.

\section{Their Classification of the Practical Sciences}

Rather than simply accepting and transferring the Aristotelian classification of the practical sciences, ${ }^{6}$ al-Fārābī and Avicenna restated it according to their own perspectives. ${ }^{7}$ In the classical Aristotelian classification, practical sciences are divided into theoretical (theoretikê), practical (praktikê), and poietical (poiêtikê) sciences. Practical sciences have three parts: ethics (êthikos), household management (oikonomikos), and politics (politikos). This threefold classification, which was transferred to Islamic philosophy and shaped Islamic philosophical

6 For more detailed information about the transmission of the classification of sciences, which originated in Ancient Greece, to Islamic world, see Organizing Knowledge: Encyclopaedic Activities in the Pre-Eighteenth Century Islamic World, ed. Gerhard Endress (Leiden: Brill, 2006). For an analysis of the classification of the Islamic sciences in Islamic thought as a whole, see Ömer Türker, "İslam Düşüncesinde İlimler Tasnifi," Sosyoloji Dergisi 3, no. 22 (2011): 533-56.

7 For more information about the late Alexandrian classification of Aristotle's books, which especially affected al-Fārābī's classification and its transmission to the Islamic world, see Dimitri Gutas, "Paul the Persian on the Classification of the Parts of Aristotle's Philosophy: A Milestone between Alexandria and Ba冈dād," Der Islam 60, no. 2 (1983): 231-67. 
studies in the practical sciences as tadbir al-nafs, tadbir al-manzil, and tadbir almudun, respectively, became the classical form of ethical studies after Nașir alDīn al-Ṭūsī (d. 672/1274). But since al-Fārābī and Avicenna changed this classical classification, it does not apply to their practical philosophy. Considering their additions and eliminations to the classical classification of the practical sciences, one can see the first signs of their disagreements on practical philosophy that, at some point, depends upon how they understood the religion-philosophy relation.

Al-Fārābī's classification, which appears in his Iḥṣẩ al-'ulūm, places practical philosophy under "al-'ilm al-madanī." 8 Thus, not only does he eliminate household management from the Aristotelian classification of the practical sciences, but he also adds fiqh and kalām to that practical field's remaining subjects, namely, ethics and politics. ${ }^{9}$ Al-Fārābi posits ethics and politics as the parts of a whole that can be completed only with each other. ${ }^{10}$

According to him, ethics is "a science which presents that the aim of dispositions, behaviors and voluntarily actions is happiness and the things that bring happiness are goodness and virtues. As for politics, it investigates the forms and actions of a government that can provide such goodness and virtues in cities and nations." ${ }^{11}$ Although ethics and politics have been posited as two complementary parts, neither the relation of fiqh and kalām with ethics and politics nor the relation of these four disciplines is elaborated in the Ihșā. In this work, fiqh and kalām are not posited as parts of philosophical ethics and politics, for these are more like the religious sciences, which are clearly separated from ethics and politics. Moreover, they are also considered in the frame of al-'ilm al-madanì together. Al-Fārābī clarifies the relation of ethics and politics with fiqh and kalām in his Kitāb al-Milla and Kitāb al-Khurūf.

According to the frame drawn in Kitāb al-Milla and Kitāb al-Khurūf, the sciences of ethics and politics investigate individual and communal virtues and vices by means of the philosophical method. But fiqh and kalām are not philosophical

8 According to some studies in the literature, as far as accepting that all sciences except metaphysics have both a theoretical and a practical side, al-Fārābī's understanding differs from that of Aristotle. For the study that first expressed this claim, see Matthias Schramm, "Theoretische und Praktische Disziplin bei al-Fārābī," Zeitschrift für Geschichte der arabisch-islamischen Wissenchaften 3 (1986): 1-55. For supportive studies, see Druart, "Al-Fārābī on the Practical"; Hasan Hüseyin Bircan, "Fârâbînnin İlimler Tasnifi Bağlamında Siyaset ve Ahlâkın Neliği,” İslämiyāt 6, no. 4 (2003): 139-50.

9 Al-Fārābī, Iḥsā al-ưlūm, ed. Ali Bū Mülhim (Beirut: Dār wa Maktaba al-Hilāl, 1996), 79-92.

10 For the politics-ethics relation in al-Fārābī's thought, see Dimitri Gutas, "The Meaning of madanī in al-Fārābī’s 'Political' Philosophy," Mélanges de l’Université Saint-Joseph 57 (2004): 259-82.

11 Al-Fārābī, Iḥsā, 79-85. 
sciences, for they depend upon the beliefs and practices derived from revelation. A religious-based science (' $\mathrm{ilm}$ ) is limited to the judgments posited in the holy text and those that are derived from the posited ones. Since philosophical ethics and politics conduct exhaustive investigations into happiness, pleasure, honor, and their position in society, as well as in people's behaviors and dispositions, it is very broad as well as more inclusive and universal. ${ }^{12}$ The connection among them is based on the fact that fiqh and kalām's principals and universals have been found in philosophy. In other words, either theoretical philosophy or practical philosophy, which contains ethics and politics, includes the universals of those issues subjected to fiqh and kalam, which means that the latter two depend on philosophy. ${ }^{13} \mathrm{Al}-$ Fārābī already has highlighted that since philosophy is prior to religion and its universals have been found in philosophy, religion is based on it. ${ }^{14}$ Thus, the knowledge in the practical field is originally known by the intellect/philosophy, and therefore the latter's authority is essential in this field.

According to al-Fārābì, the theoretical and practical ideas that have been reached by philosophical research are stated by an imaginative and rhetorical discourse in religion. ${ }^{15}$ Consequently, although fiqh and kalām are essentially related to philosophy, they are not philosophical disciplines because their different method essentially separates them from those sciences. Al-Fārābī considered them part of the al-ilm al-madani because of their social and practical side, must be with ethics and politics. To sum up, even though he located fiqh and kalām in this classification under the al-'ilm al-madani due to their social character, he separated them from the philosophical disciplines in terms of their modality of discourse.

Avicenna speaks about his classification in several of his books, such as 'Uyūn al-ḥikma, Shifä': al-Madkhal, al-Aqsām, al-Hikma al-mashrıqiyya, and Dāneshnāme. In 'Uyūn al-hikma, he states that practical philosophy is divided into ethics, household management, and politics (khulqī, manzilī, and madanī), as is the case with the classical Aristotelian scheme. ${ }^{16}$ In Shifä': al-Madkhal, he writes that the things upon which our choice and actions depend are subjected to practical philosophy, whereas those things that do not are subjected to theoretical philosophy. Practical

\footnotetext{
12 al-Fārābī, Kitāb al-Milla, ed. Muhsin Mahdī (Beirut: Dār al-Mashriq, 1968), 53-54.

13 Fârâbî, Kitāb al-Khurūf, trans. Ömer Türker (İstanbul: Litera Yayıncılık, 2008), 69-72; al-Fārābī, Kitāb al-Milla, 46-47, 51-52.

14 Fârâbî, Kitāb al-Khurūf, 69.

15 Ibid.

16 Ibn Sīnā, 'Uyūnu al-ḥikma, ed. Abdurrahman Badawī (Beirut: Dār al-Qalam, 1980), 16.
} 
philosophy is both epistemological and practical, for it includes knowing and acting for the sake of perfecting the soul. ${ }^{17}$ Accordingly, while the aim of theoretical philosophy is to know the truth, the aim of practical philosophy is good (khayr). ${ }^{18}$

Following the late Alexandrian version of the Aristotelian classification of practical sciences, in al-Madkhal Avicenna classifies practical philosophy as individual ethics (akhlāq), politics ('ilm al-siyāsā), and household management (tadbir al-manzil). ${ }^{19}$ But in al-Aqsām, he posits two sub-disciplines under the science related to social issues on the grounds that it has two branches: (a) the one is dealing with kingship (mulk); (b) the other is concerning prophecy (nubūwwa) and divine law (shari'a). The rest of the text clarifies that the first branch is concerned with those issues that appear in the classic books of politics and that the second branch includes four main subject matters: (i) the existence of prophecy; (ii) humanity's need of the divine law (sharìa) for its existence, survival, and the afterlife; (iii) the wisdom in the universal commands and prohibitions common to all divine laws

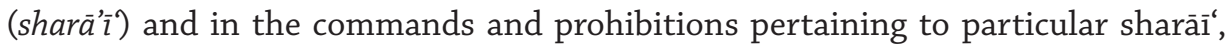
according to each particular people and time; and (iv) the difference between divine prophecy and all false claims. ${ }^{20}$ In brief, al-Aqsām basically accepts the classical threefold classification, but with a supplement that implies that politics has two aspects: philosophical and divine.

The Dāneshnāme also contains an addition to the Aristotelian classification. After defining practical science as that which declares what to do in this world and what to expect in other world, Avicenna specifies that this science is divided into ethics, household management, and politics. But he then adds that politics has two subdivisions: (a) the one is about divine laws (sharāī) (b) the other is siyāsāt (political practices). ${ }^{21}$ Since he specifies that the former is the basic part (așl) and latter is derivative ( $($ ar) ), it might be understood that sharāi' mean divine laws and that siyāsāt mean practices related to politics. Unfortunately, as Avicenna does not explain these disciplines exhaustively, we have no more information about the two sub-sections' dissimilarities.

17 Ibn Sīnā, al-Shifâ'/al-Mantiq I: al-Madkhal, ed. Fu'ād al-Ahvānī et al. (Cairo, 1952), 12. (Hereafter: alMadkhal)

18 Ibid., 14.

19 Ibid.

20 Ibn Sīnā, "Risāla fī aqsām al-'ulūm al-aqliyya," ed. Halide Yenen, "İbn Sînâ'da İlimler Tasnifi ve Risāle fì Aksām el-Hikme," Kutadgubilig 14 (2008), 85.

21 Ibn Sînâ, Dânişnâme-i Âlâî: Alâî Hikmet Kitabı, trans. Murat Demirkol (İstanbul: Türkiye Yazma Eserler Kurumu Başkanlığı Yayınları, 2013), 134. 
In his al-Hikma al-mashriqiyya's section on logic, Avicenna expresses his general views about the sciences. He summarizes the practical sciences into three sections: ethics (the science that investigates how to attain happiness this life and the hereafter in relation to nafs and its states), household management, and politics, both of which acknowledge the duties in terms of living commonly. But Avicenna also contends that since common things must be determined by law, household management and politics cannot be completely separate even if they might have different governors and laws. Thus, they are in need of one law-giver, namely, Prophet. He clearly suggests that even if these three sections are separate disciplines, all of them require a common legislative art, which he calls al-șinā'a al-shāri' $a$ (the legislative art). As Avicenna closes this discussion with "therefore, as theoretical sciences are four, numbers of practical sciences are four too," it is understood that he accepts practical sciences. But unlike the Aristotelian threefold scheme, he adds al-șina' $a$ al-shäri' $a^{22}$ and presents it as the one that legislates for all of the other practical sciences. Therefore, it must also be hierarchically superior to them.

Now then, contrary to al-Fārābī, who inserts fiqh and kalām to practical sciences but implies a separation for them from ethics and politics, Avicenna adds to the practical disciplines a science that is related to prophecy and divine law but does not clarify its relation to the philosophical and practical sciences. The following chart reveals the differences between the two philosophers' classifications of the practical sciences.
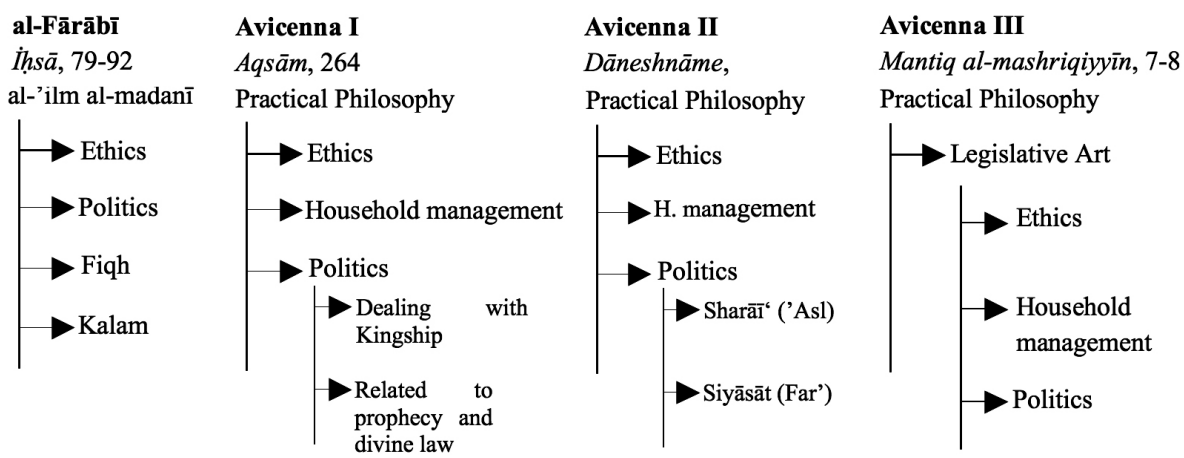

Although Avicenna presents a different classification of them in his separate works, the common change among them is his addition of a science/art related 
to religion, in other words, related to divine law and prophecy. In some of his works he places this science under politics; however, in his Mantiq al-mashriqiyyin it is placed above all of the practical sciences. This is where one encounters the controversial interpretations of this supplemental practical discipline: Does this discipline have the authority to determine the practical field or not? Muhsin Mahdi, basing himself on its placement under politics in al-Aqsām, asserts that the job of politics is to investigate the subject matters of the discipline dealing with divine law and prophecy and therefore claims that Avicenna considers religious matters part of politics. He argues that the divine law's epistemological authority is limited to those issues related to individual ethics, such as the nafs and its perfection, death, and life in the hereafter. Mahdi excludes social disciplines (e.g., household management and politics) because of their communal aspect. Moreover, he conjectures that in Avicenna's philosophy, politics must be understood as having authority over, as well as being hierarchically above, all practical disciplines. But Mahdi overlooks the practical classification in al-Hikma al-mashriqiyya and never even mentions this book. ${ }^{23}$

In contrast, James W. Morris refrains from connecting this "nameless" science indicated in al-Aqsām to politics. In his article on Avicenna's political thought, he calls attention to the vagueness of the philosopher's position. Although he found the silence about the details of this "nameless" science astonishing, Morris thinks that interpreting the issue as Mahdi did, in the way inspired by al-Fārābī, would be rash and incorrect. Furthermore, he comments that Avicenna's avoidance of mentioning al-Fārābī in those passages that supposedly show the limits of politics indicates a fundamental disagreement between them about this issue. Morris argues that the classification in al-Hikma al-mashriqiyya might seem to be an attempt to connect practical philosophy to prophecy and divine law, whereas alFārābī clearly separates practical philosophy from fiqh and kalām. ${ }^{24}$

23 Mahdi, “Avicenna: Practical Science," 86-87. One can see the traces of Mehdi's mentor Leo Strauss (d. 1973) in this approach. The Straussian approach claims that al-Fārābī's main concern was only politics, which depends on theoretical and practical perfection. However, in his writings, he used a method that hides his real intention/concern in order to avoid from public reaction. By interpreting the entire history of Islamic philosophy from the same perspective, this approach naturally presents Avicenna as al-Fārābī's follower who centered politics and placed the science related to religion under politics. For some analysis of the Straussian approach, see Dimitri Gutas, "The Study of Arabic Philosophy in the Twentieth Century: An Essay on the Historiography of Arabic Philosophy," British Journal of Middle Eastern Studies 29, no. 1 (2002): 19-25; Oliver Leaman, “Does the Interpretation of Islamic Philosophy Rest on a Mistake?" International Journal of Middle East Studies 12 (1980): 525-38. 
Another objection to Mahdi's approach can be seen in M. Cüneyt Kaya's articles on Avicenna's understanding of practical philosophy, where he proposes an understanding that centers the concept of al-șinā' $a$ al-shāri' $a$ (the legislative art) as the authority for the practical field. Indicating that the differences in Avicenna's classifications might be due to the evolution of his ideas (and therefore changed ideas) about practical philosophy, Kaya thinks that the classification in al-Hikma al-mashriqiyya might be considered his final position. ${ }^{25}$ According to him, since Avicenna clearly states in this book that "practical philosophy consists of these four disciplines," one can think that his presentation of al-șinā'a al-shāri'a in alHikma al-mashriqiyya completes what he stated in al-Aqsām and Dāneshnāme. ${ }^{26}$ Consequently, the four issues presented in al-Aqsām as the subject matters of the science dealing with prophecy and divine law, which Mahdi had related to politics, might reasonably be seen as the content of the legislative art. ${ }^{27}$ Besides, Kaya also thinks that the chapters about the need of prophecy, the practical philosophy discourses at the end of Shifä': al-Ilāhiyyāt, and some passages in the chapters about al-maqūmāt al-'ārifīn al-Ishārāt implies the content of the legislative art. ${ }^{28}$

Kaya attempts to reconcile the ideas about the religion-practical sciences relation in Avicenna's other books with the concept of al-șinā'a al-shāri'a. According to him, Avicenna's practical philosophy comprises ethics, household management, politics, and al-șinā'a al-shāri'a. However, this latter sub-field is hierarchically superior because it analyzes the legislative power of religion, which poses universals, principles, and particular applications of these practical disciplines. This science, which explores the nature of the Prophet's legislation within the framework of various subjects (e.g., prophecy, its role in society, its legislative power, and the goals and scope of this legislation), is hierarchically superior because of religion's determinative authority in Avicenna's philosophy. Moreover, since it provides the practical sciences' main concepts, principles, and premises, it is a universal discipline. And because it is related to the theoretical field, it serves as a bridge between metaphysics and practical philosophy. Avicenna," Arabic Sciences and Philosophy 24 (2014): 275.

26 Kaya, "Peygamberin Yasa Koyuculuğu," 71-82.

27 Ibid.,79-80.

28 Kaya presents his chart in order to show those of Avicenna's books that contain some chapters about the legislative art. See M. Cüneyt Kaya, "Prophetic Legislation: Avicenna’s View of Practical Philosophy Revisited," Philosophy and the Abrahamic Religions: Scriptural Hermeneutics and Epistemology, ed. Torrance Kirby, Rahim Acar, and Bilal Baş (Newcastle: Cambridge Scholar Publishing, 2013), 215. 
Kaya thinks that Avicenna saw no reason to write about philosophical ethics and politics due to the authoritative nature of this discipline, which determines practical field on the basis of theory and practice. Therefore, both he and Morris believe that Avicenna cannot be seen as following al-Fārābī in the practical field. Furthermore, Kaya thinks that Avicenna's practical philosophy contains an implicit criticism of al-Fārābī's approach in that field. ${ }^{29}$ Unfortunately, those chapters alHikma al-mashriqiyya that would be expected to have elaborated upon the nature of al-șinā'a al-shäri' $a$ have not survived, which means that the accuracy of Kaya's claims cannot be evaluated.

At this point, in contrast to al-Fārābī's indisputable positioning of "intellectual/ philosophical determination" in the practical field, there are two opposite interpretations of Avicenna's practical philosophy: (1) his classification implies "political/philosophical determination" and (2) his approach to the practical field contains an obvious "religious determination." These two opposing interpretations affect the comparison al-Fārābī and Avicenna's practical philosophy, because the former contends that philosophy is prior to religion and thus gives religion its universals and principles. Whereas an interpretation that asserts the "philosophical determination" of Avicenna's practical philosophy implies the approval of al-Fārābī's practical philosophy, an interpretation that asserts that "religious determination" means rejecting al-Fārābī's practical philosophy. Here, we should consider those of Avicenna's other books in which he states his general philosophical approach in order to explore his understanding of philosophy, religion, and the practical sciences. Doing so will allow us to ascertain his approach to religious determination in the practical field independently from the classification of the practical sciences. At this point, questioning both philosophers' approach to the problem of the source of "good" and "bad," namely, morality is a good way to explore their ideas about what is determinative element in the practical field.

\section{The Source of Morality}

Whether the differences between the two philosophers' classification of the practical sciences emerged from a more fundamental disagreement over their practical philosophy will hopefully appear in their approach to the source of morality. Initially, we observe that al-Fārābī emphasizes the intellect's function without 
referring to religious knowledge at all. Therefore, he clearly accepts the intellect as the source of morality. In his system, the human being's intellectual faculty is the closest thing to the universe above the Moon. The intellectual faculty transforms from potentiality to actuality by means of the touch of the Active Intellect. The touch that transforms the potential intellect into the actual intellect gives the first intelligibles to the potential intellect. ${ }^{30}$ In his Ārā', al-Fārābi enumerates the common first intelligibles and mentions the principles that enable one to qualify human actions good and bad among them:

\begin{abstract}
The common first intelligibles are three: the first principles of geometry; the first principles by which one knows good and bad (jamill and qabih h) in human actions; and the first principles that are used in order to know the facts of those existences that do not depend on human actions such as the heavens, The First Cause, other first principles, and the things that came from these principles ${ }^{31}$
\end{abstract}

Even though al-Fārābī did not define these first common moral intelligibles, ${ }^{32}$ this passage clearly reflects his belief in the existence of a practical science that depends on universal and necessary principles. Besides, he also states unambiguously that some of the practical field's main premises, such as "happiness is the ultimate aim of morality" and "happiness is actualized by perfection of the intellect, which is the essence of a human being," are also obtained by theoretical intellect:

Happiness, which human beings can know and perceive, is known by the theoretical intellect, not by the other faculties. This is known by using the first principles and primary knowledge that are given only by the Active Intellect. When a human being knows [happiness], desires it by his appetitive faculty (quwwa nuzüìya)...33

According to his philosophy, the practical field also depends on the knowledge obtained by the theoretical intellect in terms of main principles. ${ }^{34}$ However, those principles do not provide the whole required epistemological background to

30 Al-Fārābī, Kitāb al-Siyāsa al-madaniyya, ed. Fawzi Mitrī Najjār (Beirut: Dār al-Mashriq, 1993), 31-33 (Hereafter: al-Siyāsa); Kitāb Ārä' ahl al-madīna al-fādilila, ed. Albert Nāsrī Nādir (Beirut: Dār al-Mashriq, 1985), 101-03 (Hereafter: Ārā').

31 Al-Fārābī, Ārā', 103.

32 For a comparative analysis of the arguments about what these first intelligibles are, see: Özturan, Akıl ve Ahlāk.

33 Al-Fārābī, al-Siyāsa, 73. For similar passages, see al-Fārābī, Ārā', 107; al-Fārābī, Fuṣūl muntaza'a, ed. Fawzi Mitri Najjār (Beirut: Dār al-Mashriq, 1986), 62.

34 Al-Fārābī, Kitāb Taḥṣil al-sa 'āda, ed. Jāfer Āl Yāsīn (Beirut: Dār al-Andalus, 1983), 74-75 (Hereafter: Taḥșill). 
produce a moral person, al-Fārābī divides all intelligibles into natural (al-ma 'qūlāt al-țabīiyya) and voluntary (al-ma 'qūlāt al-irādiyya). Those that depend on nature rather than the nafs are "natural intelligibles," and those that depend on the will "voluntary intelligibles." ${ }^{35}$ As those in the latter group are strictly related to the specific case's surrounding circumstances (al-aḥwāl al-muțifa) and thus cannot be completely grasped by the theoretical intellect, they belong to the practical intellect. In a specific case, the practical intellect should consider all of the surrounding circumstances (i.e., its time, place, agent, subject, means, and aim) in order to actualize the principle grasped by the theoretical intellect. ${ }^{36}$ Evaluating these will enable one to determine the action's quantity, quality, and duration. ${ }^{37}$

It would be extremely difficult for the practical intellect, when considering all of these circumstances, to find its way by itself. At this point, al-Fārābī reminds us that a person would be in need of experience, perhaps his or her own, but also might benefit from the experience of humanity as a whole. In this way, generally accepted (mashhür) and experimental (tajrībì) premises assist both the theoretical and the practical intellect. Even if they do so in an indirect and limited way, they become the source of morality in a certain sense as well. ${ }^{38}$ In other words, even if these premises are not the first premise, which expresses the universal principle in a practical syllogism, they are used as the second premise and thus affect the outcome. ${ }^{39}$

Thus far, al-Fārābī has given the impression that intellect and experience provide complete and correct moral knowledge, so that a person who has attained intellectual perfection and enough experience can act morally even in the absence of religious or any other moral source. ${ }^{40}$ However, fully aware that not every person can acquire the required intellectual and experimental perfection because everyone's nature differs due to various factors (e.g., climate, flora, parents' diet, movements of the existents of below and above the moon at the time of birth), not everyone can learn philosophy, which is a long and difficult journey. Or, even if a person is capable, he or she might not have enough facilities to see this tough journey through to the end. ${ }^{41}$ In this case, the laws and sanctions posited by political or

36 Al-Fārābī, Risāla al-Tanbīh 'alā sabīl al-sa'āda, ed. Sahban Halīfāt (Amman: al-Jāmi‘a Urduniyya, 1987), 197 (Hereafter: al-Tanbīh).

37 Al-Fārābī, al-Tanbīh, 196-98; Taḥșìl, 68.

38 Fârâbî, Kitāb al-Khurūf, 71.

39 Özturan, Akıl ve Ahlâk, 152.

40 Al-Fārābī, Fuṣūl, 45-46; Ārā', 105-106; al-Siyāsa, 81-82.

41 Al-Fārābī, al-Siyāsa, 69-71. 
religious authorities must intervene. By being a governor, a philosopher legislates some rules that everyone should obey; by being a person who has the quality of being a religious leader, he does so by religious rules. Al-Fārābī contends that as a religious leader, a prophet receives theoretical knowledge from the Active Intellect. But he also receives a particular kind of knowledge, namely, beliefs and practices, to his imagination (mutahayyila). He then presents this knowledge by means of signs, metaphors, and particular examples, ${ }^{42}$ thereby publicly transferring moral rules and measures to people via religious authority.

But regardless of whether it is directly obtained by intellectual perfection or by laws made by the political or religious authorities, moral knowledge depends on the Active Intellect ( $a l$-' $^{\prime} a q l$ al-fa' $\bar{a} l$ ). Since this Intellect emanates from God, it is safe to say that morality comes from a divine source. Al-Fārābī, however, argues that it is both possible and ideal to acquire accurate knowledge of moral actions only by attaining theoretical and practical intellectual perfection. On the other hand, religion's function as a source of morality is indirect, it is for people who cannot attain intellectual perfection, its language is symbolic and religious practical knowledge is mostly in the form of rules and practices. ${ }^{43}$

As Avicenna's identification of morality's source is not as clear and consistent as al-Fārābī's, the secondary literature on his moral approach contains some contradictory interpretations, some of which also overlook the different points that he emphasized in his separate books. To avoid a similar mistake, I will analyze Avicenna's related passages one by one and then present a consistent and accurate interpretation of his answer. Initially, I will focus on those passages that indicate the relation between morality and intellect. This passage in al-Birr wa al-ithm states that the intellective faculty's (al-quwwa al-nātiqa) function is, as a whole, in the practical field:

43 Druart adds a third stage to what I pictured here as two stages (the philosophical and religious expression of practical knowledge). In this stage, which Druart he calls "pre-philosophical," practical knowledge is presented in a persuasive method to a person who will be a student of philosophy in the future (iqnā'î̀). According to al-Fārābī, a student of philosophy should be prepared morally before his philosophical education. Since he is not able to learn morality in a philosophical way yet, he should learn it in a different method at the beginning. According to Druart's formulation, religious expression uses poetic and rhetoric arguments, philosophical expression uses demonstrative arguments and pre-philosophical expression uses dialectical arguments. Therefore, only philosophical expression states the universal and necessary approach. Druart, "Al-Fārābī, Ethics and First Intelligibles," 414. 
The intellective faculty (näțiqa) is the power by which human being acts his actions and thinks about the particular and specific cases (rawiyya), acquires sciences and arts, and discerns (tamyīz) good and bad (jamīl and qabìh) in actions. ${ }^{44}$

It appears here that he identifies the function of intellectual power as being for comprehending good and bad. But his most evident expressions about morality's source appear in this passage of al-Ishārāt:

The human soul, which has the qualification of intellect, is a substance that has faculties and perfections. Some of the faculties are directed to what a human being needs for the management of his body. This faculty is specially known as practical intellect, which deduces what should be done in order to achieve the aims that he chose (ikhtiyarr) from the primary (awwalī), widespread ( $\left.z \bar{a}^{\prime} i\right)$ and experimental premises (tajrībi $)$. It achieves this by the help of theoretical intellect at the moment of moving from universal view to the particular. ${ }^{45}$

Avicenna clearly states that an intellectual process moving from universal principles to particulars is happening at the level of practical thinking. Even though such thinking is the practical intellect's job, it seems that the theoretical intellect also has a share to help at inducing a particular judgment from a universal principle. But most importantly, he is saying that the action's aim depends on primary, widespread, and experimental premises. At first glance, this means that the source of practical knowledge is both (because he mentions primary premises) the intellect itself and (because he mentions widespread and experimental premises) human experience. But in his Ahwwāl al-nafs, Avicenna admits that the source of moral propositions cannot be the intellect itself:

(...) Ammila, as a concept, is the faculty that is the base of particular bodily movement of human beings that depends on thinking about particulars (rawiyya). The faculty of ammila can be thought of [i] in terms of the animal appetitive power (hayawānī nuzūî̀) [ii] in terms of animal-imaginative and estimative faculty (hayāwānī mutahayyila wa mutawahhima) and [iii] in terms of itself. [i] In terms of animal appetitive power, the faculty of ämila is the source of states of soul (hay'a) such as fear, embarrassment, and laughter and so on, which we tend to by means of affecting quickly and get affected. [ii] The faculty of ammila, in terms of animal-imaginative and estimative faculty, uses the imaginative and estimative faculty to manage the things subjected to generation and corruption (al-kawn wa al-fasād) and in deducing the human arts (șinā‘a). [iii] As

44 Ibn Sīnā, "Risāla al-Birr wa al-ithm," al-Mazhab al-tarbawī 'inda Ibn Sīnā, ed. Abdulamr Shamsaddin (Beirut: Sharika al-'Ālamiyya lial-kitāb, 1988), 361.

45 Ibn Sīnā, al-Ishārāt wa al-tanbīhāt, II, ed. Suleiman Duniā (Cairo, 1985), 387-88. 
for the faculty of ämila in terms of itself (i.e., when we think it without qualification), the generally accepted views such as "lying is bad" and "injustice is bad," which are not purely intellectual as mentioned in the books of logic, emerge between the theoretical intellect and itself (viz., the faculty of ämila). ${ }^{46}$

In this passage, even though he again states that our practical knowledge depends on widespread and generally accepted premises, he does not mention primary premises. Moreover, he specifies that these propositions cannot be purely intellectual, for they must be coming from somewhere between the theoretical and the practical intellects. In other words, these moral propositions are formed with the help of these two intellects. Thus, at this point it seems safe to say that Avicenna's philosophy has an intellectual base of morality. As a supporting passage, Deborah Black also points this out in Shifä': al-Khatäbe:

\begin{abstract}
As we clarified before, demonstration is not useful in order to lead masses (jumhür) to a true common conviction (al-'aqd al-haqq). An also we clarified that the art which has the task of justification of this judgment is rhetoric. One of the virtues of this art is that it does not in need of demonstration in order to establish this kind of aims. As it explained before, there are judgments in particular cases which correct practical wisdom (ta'aqqul) requires. And this correct practical wisdom does not depend on rhetoric and dialectic (muhāwara), in reverse, its rules are deliberation about particulars (rawiyya) and theoretical thinking about universals (nazar) in the same way demonstration concerning theoretical and universal matters depend on truth, does not depend on dialectic (jadal). ${ }^{47}$
\end{abstract}

Since Avicenna is separating practical wisdom from rhetoric here, Black concludes that former must depend on more than the premises on which the latter depends. To put it another way, rhetoric already depends on generally accepted and generally received premises. If practical philosophy depends only on these premises, there would be no difference between practical science and rhetoric the exact thing that Avicenna is denying in this passage. ${ }^{48} \mathrm{He}$ is also saying that practical reasoning is based on both thinking on particulars and universals, as if explaining the expression in Ahwwäl al-nafs. Depending on this, Black asserts that even if al-Fārābi and Avicenna's practical approaches might seem fundamentally contradictory, since they depend on similar ideas about morality's theoretical

47 Ibn Sīnā, al-Shifä'/al-Manțiq VIII: al-Khatāba, ed. Ibrāhīm Madkūr (Cairo: el-Mațba'a al-'Āmiriyya, 1954), 22.

48 Black, "Practical Wisdom," 458-59. 
base, one cannot actually say that they are mutually exclusive, for they both accept that the practical field depends on a theoretical and intellectual base in terms of universal and principal grades. Black claims that the only difference is that alFārābī's emphasis on this theoretical and intellectual base is considerably more intense than Avicenna's. ${ }^{49}$

Saying that the practical field has theoretical principles does not necessarily mean that moral knowledge is obtained by these principles. That is, saying that one can indicate the theoretical background of rules and virtues in the practical field is not the same as saying that practical rules and virtues are deduced from theoretical principles. The first one would indicate an approach to practical knowledge that can also be formulated in a theoretical base, and the second one would indicate a practical knowledge that is obtained only by reasoning. Black further points out that nuance: Even though both have a theoretical base, one cannot see in Avicenna an understanding of an independent practical science that depends on obtaining these theoretical principles by intuition (hadth) in a demonstrative method. ${ }^{50}$

One expects an independent practical philosophy approach to explain the process from obtaining theoretical principles to the moment of making a specific practical decision and also to clearly express their relation to such moral concepts as disposition, virtue, and so on. Black calls attention to the lack of any clarification in Avicenna's philosophy about obtaining theoretical principles and then using them in practical reasoning on particular cases. Butterworth, who also wrote about this issue, asserts that the most deceptive point in Avicenna's practical approach is his silence on the relation between theoretical intellect and obtaining dispositions and virtues. ${ }^{51}$ Both of their points seem generally accurate; however, without understanding the factor of "religious determination" in the practical field, which Butterworth does not mention and Black only implies at the end of her article, one cannot envision Avicenna's practical approach correctly. Therefore, I will attempt to illustrate Avicenna's approach about the source of morality by considering this factor.

Avicenna expresses his ideas about religious determination in the field of practical philosophy and in the frame of determining the source of practical knowledge most clearly in his Shifä': al-Madkhal and 'Uyūn al-hiikma. After stating that practical philosophy consists of ethics, household management, and politics, he writes in al-Madkhal:

\footnotetext{
49 Ibid., 460.

50 Ibid., 457, 461.

51 Butterworth, "Medieval Islamic Philosophy," 243.
} 
The truth of all these is verified (tahqiq) by theoretical demonstration and the testimony of religion (bi al-shahāda al-shar ìyya) and its elaboration in detail (tafșill) and its judgment (taqdìr) are by means of divine law (sharî'a). ${ }^{52}$

According to this, even though the intellect can analyze and justify practical knowledge, more fundamentally, divine knowledge, which comes from the Prophet, determines the practical field, which is individual, political, and domestic (in the family) human actions either in the form of principle or of particular practices. To put it another way, even if intellectual activity is possible in the practical field, originally both general principles and particular judgments belong to the field of religious authority. The following passage in 'Uyūn al-hikma also confirms "religious determination" in the practical field:

The parts of practical philosophy are social philosophy (al-hikma al-madaniyya), household management (al-hikma al-manziliyya), and ethics (al-hikma al-khulqī). The principles of these three are acquired from religion (al-sharí'a al-ilähiyya) and the perfections (kamālāt) of their borders ( $h u d \bar{u} d$ ) are explained by divine religion..$^{53}$

Clearly, in Avicenna's philosophy religion has an absolute authority not only in morality, as Mahdi claims, but also in all three disciples of the practical field. ${ }^{54}$ Furthermore, this authority is so comprehensive that it determines an agent's action in terms of the quality, quantity, time, and form. The concepts of tafșill (exhaustive determination), taqdìr (judging), huudūd (defining the limits), and kamālät (explaining its perfection) in the passages quoted from al-Madkhal and 'Uyün reveal this determination. Now then, it becomes obvious that both philosophers have a completely different perspective about morality's source. AlFārābi argues that one can acquire moral knowledge as universal principles and particular practices by intellectual perfection alone, thus obviating the need for religious knowledge, as well as act in accord with this intellectual knowledge with the help of experience. Avicenna, conversely, does not speak about such an intellectual process and possibility, which gives the impression that his philosophy holds that proper moral knowledge and action must originate in religion. ${ }^{55}$ Thus,

52 Ibn Sīnā, al-Madkhal, 14.

53 Ibn Sīnā, 'Uyūn al-ḥikma, 16.

54 Following this passage, Avicenna says that theoretical philosophy also acquires its principles from religion. But these principles, which differ from the practical ones, are posited by way of implication and remark ('alā sabìl at-tanbìh). According to him, the task of theoretical philosophy is to detect such principles and prove them ('alā sabìl al-ḥujja). Ibn Sīnā, 'Uyūn al-hikma, 17.

55 Ömer Mahir Alper, İslam Felsefesinde Akıl-Vahiy Felsefe-Din İlişkisi (Istanbul: Ayışığı Kitapları, 2000), 155, 167-69, 204-05. 
the sole function of both theoretical and practical reasoning is either to obtain a better understanding of religious moral principles or to deduce judgments in those cases for which religion provides unclear statutes. But of course these new judgments must not exceed religion's limits.

Even if some of Avicenna's passages by themselves might seem to imply that he believes that intellectual authority determines the practical field, considering all of the passages about the source of moral knowledge reveals that one cannot speak about the authority of absolute reasoning in the practical field. Compared to Avicenna's view of the theoretical intellect's limited function, al-Fārābī's philosophy regards its contribution to the practical field as vital, as sine qua non. The most obvious sign that the theoretical intellect is morality's source is, according to alFārābī, the fact that it provides the ultimate aim and the main principles of good and bad. This is a marked contrast to Avicenna's system, in which the theoretical intellect has no direct function in terms of a moral act, but only a limited one related to the epistemological expression of morality.

Although Avicenna's passages about religious determination in the practical field are indisputable, how would one interpret those of his passages that indicate the function of primary premises (awwali ) and intellect by itself in morality? If such a determination exists, then what would be expected from the intellect in terms of a practical investigation? More clearly, where would it be used in a practical study of these previously quoted primary, widespread, generally accepted, and experimental premises? This passage from Shifä': al-Ilāhiyyāt can give an idea about what kind of knowledge we can acquire from religion and intellect in practical field:

\footnotetext{
You should know that some part of the subject of the life hereafter is learned from divine law and its proving is possible only by confirming the knowledge of divine law and prophecy. This is the part that deals with the state of the body in resurrection. The wellness and evils of the body are already known, so there is no need to learn these. Undoubtedly, the true divine law brought by our Prophet, our master and our guide Muhammad - May Allah show mercy and give peace to him and his family - explains the state of bodily happiness and misery. As for some other part, it is perceived by the intellect and demonstrative syllogism, and prophecy confirms it. ${ }^{56}$
}

Even if this passage's main concern is life in the hereafter, one understands from it that the human being cannot acquire some knowledge by the intellect, for such knowledge is acquired from religion. However, it can be justified by the intellect. 
Given that it also contains issues about the soul (nafs), this might be the case for the practical field as well. Religion is our only source for acquiring knowledge that the practical field cannot possibly acquire through reasoning. And yet some knowledge about the nafs and its happiness might be acquired by the intellect and even demonstrative syllogism. Even so, Avicenna refrains from arguing that the intellect can reach practical knowledge independent from religious knowledge and build a practical theory. The sentence "Prophecy confirms what is perceived by intellect and syllogism" also implies this idea. Moreover, the rest of the passage in 'Uyūn clarifies the function of intellect in the practical field:

(...) is explained by divine religion. Then the theoretical power of the human being acts on them by means of knowing their practical laws and applying these laws to specific cases. ${ }^{57}$

Now then, according to Avicenna, the intellect discovers the universals of religious practical knowledge and then applies them to specific cases. As discovering them is only an epistemological task, it cannot be a function of the practical intellect. Therefore, this task must be a function the theoretical intellect, either seen in the frame of theoretical philosophy or, considering the classification in al-Hikma al-mashriqiyya, in that of al-șinā'a al-shāri'a under the practical science. ${ }^{58}$ In the passage quoted from Shifä': al-Ilāhiyyāt, Avicenna specified that some divine practical knowledge might be also realized by the intellect and demonstrative syllogism. Considering this specification, one might think that the theoretical intellect also acts only to justify religious moral universals and present these principles in a demonstrative way. ${ }^{59}$

In these circumstances, the practical intellect's only task must be to apply the rules posited by divine law to specific cases. These rules might be in the religious sources as universals or specific judgments. ${ }^{60}$ If a rule is specific, then the theoretical intellect would deduce the universal principle upon which it depends. Therefore, the practical intellect's task is to apply the principles, be they either universal principles in the religious source or a specific rule deduced from its universal

57 Ibn Sīnā, 'Uyūn al-hikma, 16.

58 Kaya thinks that the task of the theoretical intellect (i.e., discovering the universal principles of religious-specific rules and proving their truth) fits into the legislative art (al-sinā'a al-shäri'a). Therefore, one who deals with these tasks must be a theoretical philosopher who is dealing with the legislative art. Kaya, "Peygamberin Yasa Koyuculuğu," 85.

59 Here, Kaya also adds the task of "proving the truth of divine laws in a demonstrative way" to the tasks of the legislative art. Ibid., 84.

60 Ibn Sīnā, 'Uyūn al-ḥikma, 16-17. 
principle by the theoretical intellect, to specific cases. One can also think that the practical intellect can deduce moral judgments for some specific cases that might be new and thus have no prior judgments in the religious sources.

Avicenna contends that we are using the theoretical intellect when inducing universal principles from specific religious laws and then justifying them, and that we are using the practical intellect when deducing judgments for specific case that are not explained in the religious texts from the religious universal principles. Here we can think that the primary, widespread, generally accepted, and experimental premises mentioned in al-Ishärāt and Ahwāl al-nafs are used in this process. Since the theoretical intellect also acts - even if indirectly and just for the universals during this process, the primary premises and the premises of certitude (yaqini $)$ are mentioned among the types of premises. In other words, this might be why primary premises are mentioned in al-Ishärāt in relation to the practical field. ${ }^{61}$ Consequently, even if it is indirect and by means of the practical intellect, premises of certitude still have a share in the practical field via the theoretical intellect. The rest, however, namely that widespread, generally accepted, and experimental knowledge that were mentioned in Ahwāl al-nafs are the premises (e.g., "lying is bad" and "injustice is bad") do not depend on pure intellect, for they are acquired by theoretical intellect and experience. In other words, they are the result of the powers of ālima and àmila collaboratively.

At this point, it is understood that the field that Avicenna assigned for practical philosophy is only limited to inducing specific judgments of the practical intellect for new cases from the religious universal and particular judgments. The intellect, which is the source of morality with the help of experience independently from religion, is only responsible for deducing judgments for those specific new cases that have no prior judgments in the religious sources. But here one must ask: If practical philosophy's sole function is to deduce judgments from the religious universals in Avicenna's practical philosophy, how is it different from Islamic jurisprudence (fiqh)? ${ }^{62}$ Answering this question will reveal whether one can speak of an independent practical philosophy in his thought and whether there is any difference between

61 The passage "the theoretical intellect also helps in practical deduction" in al-Ishärāt that mentions primary premises in the context of morality's source also supports my interpretation. Thus the contradiction between al-Ishärāt and al-Shifä' in terms of the types of moral premises mentioned in these books is solved. One source that indicates this problem is Kaya, "Peygamberin Yasa Koyuculuğu," 67.

62 De Boer thinks that Avicenna left the task of practical philosophy to fiqh. See T. J. De Boer, The History of Philosophy in Islam, trans. Edward R. Jones (New York: Dover Publications, 1967), 144. 
his approach to practical philosophy and al-Fārābī's. As al-Fārābī's classification of practical sciences contains fiqh and kalām, it seems proper to continue to compare both philosophers' practical philosophy in the frame of this question.

\section{The Fiqh-The Legislative Art/The Science Related to Nubuwwa and Shar'a}

Given Avicenna's idea that divine law determines all of the practical disciplines, both universally and particularly, he thought that practical philosophy is limited to deducing judgments for specific cases that are too new to have acquired any clear legislation derived from religious sources. In this situation, would not such a practical philosophy be part of Islamic jurisprudence (fiqh)? This discipline contains four main evidences (dalà'il): the Qur'an, the Sunna, ijmā', and qiyās for legislation. The first three are the sources, whereas the fourth one is the method of legislating. Imam al-Shāfi'îs al-Risāla, the first book on Islamic jurisprudential methodology, defines qiyās as "searching a judgment for a case which is not explained its judgment in the Qur'an and Sunna." ${ }^{3}$ In Ghazzālī's definition, the emphasis on "new cases" is more apparent, for he indicates that qiyās is both an indication of intelligible as well as one of the ways of legislating for new cases by means of discovering intelligibles in the sacred texts. ${ }^{64}$

As mentioned above, al-Fārābī's version of the Aristotelian classification of the practical sciences includes fiqh and kalām along with ethics and politics. He explains the task of fiqh in his $I h s ̦ \bar{a}^{\prime}$ as:

Fiqh is the art that seeks to determine a judgment of a thing that is not ruled by the divine legislator (vādil'al-sharia $)$ through the other things which are legislated and measured. By courtesy of [figh], it becomes possible to regulate in accordance with the divine legislator's goal through the underpinnings of the law posited by religion for a community. ${ }^{65}$

Thus, he qualifies the task belonging to practical philosophy in Avicenna's thought as fiqh, which al-Fārābī considers a religious science and therefore separates from the philosophical sciences of ethics and politics - independent sciences. He is

63 Al-Shāfi'ī, al-Risāla, ed. Aḥmad Muhammad Shāqīr (Egypt: Mațba'a Mușțafā al-Bābī al-Ḥalabī, 1938), 39; eş-Şâfî, Risale, trans. Abdülkadir Şener and İbrahim Çalışkan (Ankara: TDV Yayınları, 2007), 22.

64 Al-Ghazzālī, al-Mustașfā min 'ilm al-ușūl, ed. Muhammad Sulaymān al-Ashkar (Beirut: Muassasa alRisāla, 1997), 41.

65 Al-Fārābī, Ihṣāā, 85-86. 
of course aware that the practical philosopher and the faqih have very similar jobs, and thus it is meaningful that he compares a muta'aqqil (a practical philosopher) and faqīh in Kitāb al-Khurūf. ${ }^{66}$ In this comparison, al-Fārābī's use of muta'aqqil tells us a lot in terms of its relation to the concept of ta'aqqul. Al-Fārābī's used ta'aqqul, even if not consistently, in all of his books as the counterpart of Aristotle's phronêsis, ${ }^{67}$ the latter's term for the virtue that reasons about particulars correctly and can rapidly discover the morally correct behavior in a specific case. A phronimôs (one who possesses phronêsis) rapidly reaches the morally correct particular judgment for a case through reasoning on universal principles or exemplary cases. This is very similar to what a faqīh does when dealing with for divine law. In his Kitāb al-Khurūf, al-Fārābi specifies the main thing that separates them: A muta'aqqil uses generally accepted and experimental premises as principles and depends on them to produce knowledge, whereas a faqīh uses whatever is transferred from the sharìa. ${ }^{68}$

What should be remembered here is that both of them are seeking to apply universal principles to specific cases, as opposed to acquiring the universal principles, because the practical intellect has already obtained these universals from the theoretical intellect. These universals are expressed metaphorically and symbolically as principles and rules in religion, but are expressed in a demonstrative way in philosophy. As the task of a muta'aqqil and a faqih is to produce judgments through the principles of their own disciplines, their knowledge is different. ${ }^{69}$

68 Al-Fārābī, Kitāb al-Khurūf, 71. Even if al-Fārābī here only mentions the generally accepted (mashhūr) and experimental (tajrībi) premises, as I pointed out above he had already indicated that primary premises also have a place in practical philosophy.

69 In addition to specifying the differences between fiqh and practical philosophy, al-Fārābī also separates kalām from philosophy by pointing out its task clearly by indicating in his Kitāb al-Milla that religion has both theoretical and practical aspects and that kalām and fiqh are these theoretical and practical aspects of religion. (al-Fārābī, Kitāb al-Milla, 50-52.) Religion's theoretical aspect (kalām) justifies the religious principles. Avicenna, who maintains that theoretical philosophy expresses religious principles in a demonstrative way and justifies them, does not refer to kalām in this context. But al-Fārābī thinks that the mentioned justification might be demonstrative and might use other methods as well. Because of that, al-Fārābī differentiates this task of justification from theoretical philosophy. Aware that all scholars of kalām do not accept this justification by using intelligibles, he considers and classifies kalām's different approaches. Al-Fārābī also writes that some of these scholars refrain from using an intellectual method and claim that religion already presents reality, which is beyond intellect. By citing the Prophet's miracles as a proof and the fact that he never lies, they build their own justification. Some other scholars of kalām use sensibles (mahsūsāt), generally accepted (mashhūrāt), and intelligibles (ma'qūlāt) to justify the truth of the religious principles. They benefit from those premises that fit into religious knowledge. This is the only point where kalām and philosophy intersect in al-Fārābỉ's thought. They use intelligibles for the sake of obtaining victory, not for the sake of philosophy, and do so in 
Since al-Fārābī inserts fiqh and kalām into his classification of practical sciences independently and explains their scope, these religious sciences clearly differ from the philosophical practical disciplines of ethics and politics. But since Avicenna contends that religion has the authority in the practical field, the distinction between religious sciences and philosophical disciplines in the practical field is unclear. As a result, he did not mention fiqh and kalām and their difference from philosophical disciplines, as al-Fārābì did, and thus the answer of the problem also seems vague. ${ }^{70}$ In Avicenna's thought, the legislative art (i.e., the science related to prophecy and divine law) apparently has a part that is related to fiqh. If we think that the frame drawn in al-Aqsām is the content of al-șinā'a al-shāri' $a$, we cannot just say that it only provides the base of fiqh, because this art also contains the knowledge that is subjected to beliefs, such as the existence of nubuwwa and the need for sharìa. Thus, legislative art provides the knowledge that is the base of both fiqh and kalām.

As for the relation between practical philosophical disciplines and fiqh in Avicenna's thought, one can conclude that practical philosophy's task is similar to the syllogism (qiyās) in fiqh. But fiqh also has, in addition to the main evidences (așlī) of the Qur'an, Sunna, ijmā', and qiyās, such supportive evidences (farî̀) as istiḥsān, istiṣlāḥ (mașāliḥ al-mursala), istișhāāb, and șadd al-dharā'î̀ for legislation. Moreover, the legislation is not only about moral or political issues, but also about those issues not included in practical philosophy, such as judgments related to matters of worship ('ibādāt) and punishments ('uqūbāt). Therefore, although fiqh and practical philosophy cannot be consubstantiated, there is an obvious similarity between the way of deducing judgments about ethics, household management, and politics and the function of practical philosophy in Avicenna's thought. To

an inconsistent manner. When intelligibles conflict with religious knowledge, they interpret ( $t a^{\prime} w \bar{i} l$ ) the religious text. If the problem is not solved in that way, they would say that since the religious knowledge is coming from the person who does not possibly lie, the religious knowledge is correct and the other is not. Some scholars of kalām defend some things that conflict with the sensibles, generally accepted premises and intelligibles that exemplify some similar things that conflict in other religions. Some scholars of kalām use some arguments that only seek to silence his rival, and some scholars of kalām attempt to gain victory by lying and sophism (mughālața). (al-Fārābī, Ihșāa, 87-92.

Consequently, since both the intellectual method and other methods are being used in kalām, alFārābī did not consider "justifying the religious principle" an absolute philosophical action. Instead, he places kalām as a defensive discipline under the al-'ilm al-madanī. Besides, al-Fārābī highlights that fiqh has two aspects, belief and action, just like kalām. Therefore, there are also theoretical and practical dimensions in fiqh and kalām. al-Fārābī, Ihṣā, 86; Kitāb al-Milla, 50-51.

70 Depending on the passages of al-Shifä', Ömer Türker thinks that Avicenna considers fiqh in the frame of practical philosophy. Türker, "İslām Düşüncesinde İlim Tasnifleri," 544. 
understand whether this similarity means that practical philosophy includes fiqh or a useless investigation in terms of Avicenna's thought, we should take a closer look at his writings about the subject matters listed in the frame of practical philosophy.

When compared with al-Fārābī's writings, those of Avicenna's on practical philosophy seem less and limited. As a result, most of the studies on the latter's practical philosophy focus on questioning why he did not write an independent effective and comprehensive book on ethics. ${ }^{71}$ In terms of this article, the importance of this question lies in the fact that it has been answered in the literature mostly with reference to al-Fārābī. Some works have attempted to explain the situation by asserting that Avicenna confirmed al-Fārābī's practical philosophy, which is clear and detailed enough, and thus did not focus on practical philosophy. Other works assert that he did not approve of al-Fārābī's approach to practical philosophy, which depends completely on reasoning, and, unwilling to clearly deny his master (ustāẹ) al-Fārābī, remained silent. ${ }^{72}$ But, if Avicenna's understanding of practical philosophy includes fiqh, then this question is meaningless. Instead, the main question should be why he did not refrain from writing about practical philosophy at all. If his approach melts practical philosophy into fiqh, then why did he write some chapters and passages in a philosophical way about the practical field? Depending on this background, I will now consider Avicenna's philosophical writings about the practical disciplines.

In his Shifä', al-Mubāhathāt, at-Ta'līqūt, and Aḥwāl al-nafs, Avicenna speaks about ethics, politics, and even household management. Moreover, in those

71 For some studies that include the different interpretations of the concept of practical philosophy in Avicenna, see Erwin I. J. Rosenthal, "Ibn Sīnā: The Synthesis," Political Thought in Medieval Islam: An Introductory Outline (Cambridge 1958), 143-57; Mehmet Aydın, “İbn Sînâ’nın Mutluluk (es-Saade) Anlayışı," İbn Sînâ Doğumunun Bininci Yılı Armağanı, ed. Aydın Sayılı (Ankara: Türk Tarih Kurumu Basımevi, 1984), 433-51; Aydın, "İbn Sînâ'da Ahlâk," Uluslararası İbn Sina Sempozyumu Bildirileri (Ankara: Kültür ve Turizm Bakanlığı, 1984): 117-31; Galston, "Realism and Idealism”; Mahdi, "Avicenna: Practical Science"; İlhan Kutluer, "İslam Felsefesi Tarihinde Ahlâk İlminin Teşekkülü" (PhD Dissertation, Marmara University, 1989), 229-60; Morris, “The Philosopher-Prophet”; Butterworth, "The Political Teaching of Avicenna"; Macit Fahri, İslam Ahlâk Teorileri, trans. Muammer İskenderoğlu and Atilla Arkan (İstanbul: Litera Yayınlar1, 2004); Charles E. Butterworth, "Ahlak ve Siyaset Felsefesi," İslam Felsefesine Giriş, ed. Peter Adamson and R. C. Taylor, trans. Cüneyt Kaya (İstanbul: Küre Yayınları, 2007), 293-315; Şeyma Şahinoğlu, “İbn Sînâ’da Ahlâk Sorunu” (MA Dissertation, Marmara University, 2009); Kaya, "Peygamberin Yasa Koyuculuğu."

72 As I pointed out at the article's beginning, while Muhsin Mahdi thinks that Avicenna agrees with alFārābī (Mahdi, “Avicenna: Practical Science," 86-87), James Morris asserts that the reason of Avicenna's silent about practical philosophy is his disagreement with his ustād al-Fārābī. But since he did not want to criticize al-Fārābī publicly, he stayed silent about the practical issues. (Morris, "The PhilosopherProphet," 173). Even Kaya claims that Avicenna's approach to practical philosophy can be seen as an implied criticism. (Kaya, "Peygamberin Yasa Koyuculuğu," 90). 
practical discussions he quotes such moral philosophers as Aristotle and Galen. At the end of al-Ilāhiyyāt, he defines akhlāq in the Galenic way, idealizes the Aristotelian theory of the mean, uses the Aristotelian theory of nafs, and relates ethics to the concept of happiness in the Aristotelian way. ${ }^{73}$ In his independent ethical treatise al-Birr wa al-ithm, he deals with both ethical concepts (e.g., nafs, $i^{\prime} t i d \bar{a} l$, virtue, perfection, education, happiness, justice, self-sufficiency, praxis, prudence, and praise) and ethical problems (e.g., the source of morality and the change of morality). ${ }^{74}$ This treatise, which is clearly not a source of fiqh, in fact contains completely philosophical discussions about morality, most of which are quoted from al-Fārābī's al-Tanbīh and Fusūl muntaza ${ }^{\prime} a .{ }^{75}$ In addition, some treatises in the practical field have been attributed to Avicenna, among them Risālah $f \bar{i}$ 'ilm al-akhlāq and Risālah fì siyāsāt al-manziliyyah; however, they might not be authentic. These treatises also include the Platonic theory of the tripartite soul, the Aristotelian theory of the mean, and Bryson's household management ideas. Also, Avicenna mentions that he intends to compose one book at the beginning of al-Madkhal. But we know that he did (could) not write such a book. ${ }^{76}$

Even if leaving aside those books whose authenticity is unclear as well as alBirr, which Avicenna wrote at his very early ages, ${ }^{77}$ there are still some passages in philosophical method about all of practical disciplines. Furthermore, there are many traces of antic (e.g., Plato, Aristotle, and Galen) and Islamic philosophers (e.g., al-Fārābī) in these passages. Thus, we must ask once again: Even though Avicenna believed that religious authority determined all the elements of practical philosophy, both in principle and in their specific applications, why did he write about practical philosophy, mention philosophical discussions of practical problems, and quote from philosophical sources and philosophers? In order to answer these questions, one needs a clue that will show his approach to classical

73 İbn Sînâ, Metafizik, II, 176-77.

74 For the relation of this risāla with Risāla fì 'ilm al-akhlāq see: Fatih Toktaş, "İbn Sînâ'nın Risâle Fî 'İlmi’lahlâk Risalesinin Takdim, Tahkik ve Çevirisi,” DEUIFD XLIII (2016): 7-52.

75 As a source that shows the quotations one by one, see Jules Janssens, "Al-Birr wa'l-ithm, Piety and Sin: Possible Farabian Influences on the Young Ibn Sīnā," Ishraq: Islamic Philosophy Yearbook III (2012): 412-22.

76 Ibn Sīnā, al-Madkhal, 11.

77 It is thought that Avicenna wrote this treatise when he was around 22 or 23 years old. Janssens, "AlBirr We'l-Ithm," 412; Dimitri Gutas, Avicenna and the Aristotelian Tradition (Boston: Brill, 2014), 19. This might why there is a significant number of quotations from al-Fārābī in this treatise. But since there are still some chapters and passages about Avicenna's practical philosophy, this situation does not affect my argument. 
philosophical sources of ethics, politics, and household management. I would argue that this passage from al-Mubāhathät gives the clue we need:

(...) In the same way, they meant [by practical philosophy] politics and knowledge of household management and social management. Again, contrary to [practical wisdom as a virtue], it is the knowledge of all things that are subjected to our actions, whether in terms of our habits and affections or in terms of the outsiders with regard to collaborative [actions]. This knowledge is not innate (gharīzi); on the contrary, it is acquired [later] and only by theoretical reasoning (nazar) and practical reasoning (rawiyya) and syllogism that produces laws and universal rules. The books of ethics and politics already give these [laws and universal rules]. When we learn these books, we acquire this knowledge and these [laws and universals rules] become as absolute knowledge in us. ${ }^{78}$

In this passage, Avicenna indicates that the books of ethics and politics include "acquired knowledge." This implies that he both pays attention to the philosophical books on ethics and politics, even if they do not depend on religious sources, and thinks that they are important in terms of building an epistemological background for the practical disciplines. We might relate this to Avicenna's approach about the views of majority (jumhūr) in Shifä': al-Ilāhiyyāt, where, after stating that heavenly souls know particulars, prayers, and worships that make possible the reasons of some specific cases, he says that there is a reward and punishment for good and evil in the hereafter. Everything is determined for the sake of benefit in accordance with providence ('ināyah); however, evil prevents the good from happening. In this context, it comes to ethics, and Avicenna says:

Most of the things that the majority (jumhür) confirms and accepts are true. The people who guided the majority to this without knowing its reasons ('illa) and causes (sabab) are people who look like philosophers. Undoubtedly, we wrote Kitāb al-Birr wa al-ithm in this context. Learn the explanation of these from this book and confirm what is reported about the punishments that are sent to the corrupted cities and unjust people. See how Allah (the Truth) helps! Know that this is the reason of the things such as prayer, charity so on and unjustness and sins. Because, the principles of all things depend on nature, will, and coincidence. ${ }^{79}$

What Avicenna means here is the issues he mentions in the discussion of "benefit of prayer $\left(d u^{\prime} \bar{a}\right)$ in al-Birr. He says that a sincere prayer creates a conceptualization 1371), 190.

79 İbn Sînâ, Metafizik, II, 182-85. 
(tașawwur) directed to good (khayr) and another one directed toward things that make this good possible. This prayer also shows that the one performing it deserves the possible situation that he/she wishes, and then the situation happens because "the principles of this conceptualization become the reason of their existence." Here, this existent is a specific incident that happened for the sake of sincere prayer, without being caught in any barrier of evil. ${ }^{80}$ In this case, the prayer was successful and thus a disposition is directed toward the emanation that enables the soul to obtain "accurate knowledge of the action." Through this emanation, a person approaches the means that make the good possible and, if there is no barrier, it happens. ${ }^{81}$ Avicenna states that the nature that makes a prayer accepted is natural in some people, such as being a genius. But others can acquire it later on by preparing their soul through worship, prayer, and similar activities. ${ }^{82}$

Such a state of the soul can also be acquired by people who refrain from bodily pleasures, help their soul against their body, and save it from bodily disasters such as desire and anger. Even if remembering Allah and the hereafter makes being such a person easier, gives inner peace, and helps one persist in this situation, he contends that one can become such a person without thinking of Allah and His recommendations. One who is unattached to religion might also be able to get this emanation as well. ${ }^{83} \mathrm{I}$ assume that this is the explanation of "the accuracy of moral ideas of majority that is affected by people who look like philosophers" and why Avicenna refers to al-Birr after this passage.

Avicenna's emphasis on human experience in Ahwäl al-nafs can be also read in this context. According to him, humanity acquires moral universals by its own experience and transfers this knowledge as generally accepted (mashürāt) and generally received (maqbūlāt) premises to the next generations..$^{84} \mathrm{I}$ assert that this is why antic moral sources are important for Avicenna. Even if it is not religiousbased, we might benefit from those sources that include the human experience on ethics, household management, and politics. Certainly Avicenna believes that these books' subject matters were explained and measured in detail by divine law and that humanity can obtain a broader and complete knowledge about these practical

\footnotetext{
80 Ibn Sīnā, "al-Birr wa al-ithm," 357-58.

81 Ibid., 358.

82 Ibid., 360.

83 Ibid., 357-58.

84 Ibn Sīnā, Ahwāl al-nafs, 63.
} 
issues by means of religion. ${ }^{85}$ But since the concepts, ideas, and discussions in these philosophical sources acknowledge universals of the measured, legislated, and determined issues by religion, these sources are valuable. Therefore, it is reasonable to think that was the reason behind his practical philosophical writings and the justification of his intensive quotations from the earlier moral sources.

I also argue that Avicenna took these books seriously not only because of their value for their mission of transferring the accumulation of the past, but also because of their function in deducing practical judgments, for one might think that the moral knowledge obtained from philosophical books corresponds to the premises used by the practical sciences such as the primary, widespread, generally accepted, and experimental premises found in al-Ishārāt and Ahwāl al-nafs. While deducing specific judgments with the help of divine law, these premises also might be used. In other words, those premises acquired from philosophical books on practical disciplines are used in the given process of universalizing, justifying, and being applied to specific cases. That is why he paid attention to and made references to these ancient sources. Consequently, in his practical philosophy, one function of antic philosophical accumulation is to help people understand divine law and deduce new judgments for specific cases in the frame of divine law.

Now then, it becomes clear that practical science produces judgments by using both divine laws and the knowledge acquired by theoretical and practical intellect (e.g., primary, generally accepted, and experimental premises) for deducing judgments for those specific cases that have not yet been judged by divine law. I argue that this is exactly how Avicenna understands the concept of practical philosophy. Since the knowledge acquired by philosophical books on practical philosophy might not have any epistemological value in fiqh, it would be incorrect to equalize such an approach to practical philosophy and fiqh. Even so, we also cannot say that Avicenna conceives of an independent practical philosophy and, because of that, placed divine principles and their practical applications at the base of the moral judgmental process. But we can safely say that his frame of practical philosophy has an intersection point with fiqh, but that this does not exclude antic practical philosophical accumulation. In other words, he considers both religious determination and philosophical explanation, which depends on the theoretical and practical intellect. This frame - even if not in the limit of an independent science - enables him to investigate philosophically in the practical field. In this 
manner, at the end of his al-Ilāhiyyāt he could speak about both Aristotelian moral theory and divine law in the practical field. At this point, the difference between his approach and al-Fārābī's thought is crystal clear: al-Fārābī separated religious sciences from philosophical sciences and fiqh from practical sciences in a clear and detailed manner, and in a way that does not imply any nesting to each other.

The differences that surfaced between these two philosophers are due to their different approaches to the relation among reality, religion, and philosophy. AlFārābi addresses the problem generally and within the framework of universal principles without specification, whereas Avicenna discusses the issue in the border of Islam and philosophy. Thus, rather than speaking about the possibility of harmony or conflict between religion and philosophy generally, Avicenna focuses directly on the interpretation of the relation between Islamic and philosophical knowledge. ${ }^{86}$ Fundamentally, he accepts the very similar theory of prophecy (nubuwwa) to al-Fārābī's and accepts, just as al-Fārābī does, that there are different types of people and thus different methods of reveling reality, namely, religion and philosophy. Avicenna, like al-Fārābī, also believes that prophets have a special imagination power. Besides that, he knows the intellectual knowledge that philosophers do and acquires knowledge about particulars from the Active Intellect by his imagination, which he then relays to his community. Philosophy presents the knowledge acquired from the Active Intellect in a demonstrative way, whereas religion acknowledges the same knowledge but in a persuasive, metaphoric, and symbolic language, to the public.

However, al-Fārābī thinks that there is more than a difference of language between religion and philosophy, namely, that philosophy is prior to religion and religion depends on philosophy. Philosophy is the universal and necessary expression of reality and religion is rather contingent on local and subjective circumstances. Thus, it does not have a universal and necessary argumentation, as does philosophy, and means that philosophy comes before religion and is more general. ${ }^{87}$ Based on this understanding of religion, al-Fārābì developed an independent theoretical and practical philosophy from religion, which he considered an authority for people who are unable to acquire intellectual perfection.

Avicenna, without focusing on a scenario that is independent from religion, built his philosophy on the idea that Islam is the last true religion and provides 
eternally valid laws. He states that religion presents the principles of theoretical philosophy as symbols and implications, but also presents both the principles and specific practices of practical philosophy, ${ }^{88}$ among which are some truths that human beings cannot discover by using the intellect. Therefore, religion is not an alternative to philosophy, but rather has authority over it. Contrary to al-Fārābī, who prioritizes philosophy, Avicenna prioritizes religion and gives it determinative position. ${ }^{89}$ As a consequence, one can easily understand that the two philosophers' differences in understanding practical philosophy arise from this core disagreement on which one has priority.

\section{Conclusion}

This article, which attempted to compare al-Fārābī and Avicenna's practical philosophy, reveals that the first separation between them occurs in their classification of the practical sciences. Even though al-Fārābī's includes fiqh and kalām, he writes in his various books that the religious and philosophical sciences are separate fields. He therefore opens an independent space for philosophical ethics and politics and implies that a philosophical investigation in the practical field gives accurate and sufficient results. Furthermore, while prioritizing philosophy over religion, he bestows absolute authority upon intellect/philosophy in both the theoretical and practical fields. To the contrary, Avicenna adds a science, one that is related to shari'a and nubuwwa, to his Aristotelian classification of practical philosophy; however, in some of his books he places it under politics, and in one book above all of the practical disciplines. His failure to elaborate the content of this science gives rise to a disagreement over his practical philosophy in the secondary literature. I call the two main approaches "religious determination" and "political/philosophical determination." Since al-Fārābī’s approach clearly requires

89 Janssens interprets Avicenna's approach to practical philosophy as a religious project. Jules Janssens, “Ibn Sīnā (Avicenna): Un projet 'religieux' de philosophie?" Was ist Philosophie im Mittelalter? ed. J. A. Aertsen and A. Speer (Berlin \& New York: Walter de Gruyter, 1998). Gutas criticizes the fact that Janssens' interpretation depends on the idea that Avicenna considers philosophy below religion. Instead, Gutas interprets Avicenna's philosophy as an attempt to find a philosophical context for religion. He contends that Avicenna's philosophy is an attempt to connect philosophical issues to an Islamic frame. Gutas' idea is that the result of this attempt is a "better philosophy" rather than a "religious philosophy," as Janssens claims. Dimitri Gutas, "The Heritage of Avicenna: The Golden Age of Arabic Philosophy, 1000-ca. 1350," Avicenna and His Heritage, ed. Jules L. Janssens and Daniel De Smet (Leuven: Leuven University Press, 2002), 86. 
philosophical determination, one must decide which Avicennian interpretation is correct in order to make an accurate comparison. To determine this, I analyzed both philosophers' ideas about the origin of good and bad or, in other words, what they considered to be the source of morality.

This comparison shows that al-Färābi clearly argues that this source is both the theoretical and the practical intellect. He also says that religion provides universal and particular knowledge in the practical field for people who cannot receive knowledge via the philosophical method. Avicenna emphasizes both intellectual and religious determination in his separate books and passages. After showing the lack of an accurate, holistic, and consistent interpretation of his approach in the secondary literature, I sought to unify and reconcile all of the related passages as a consistent whole. The resulting picture contends that since Avicenna thinks that we cannot discover some knowledge without religion, he left moral authority to religion in the base of the principle and practical application. Therefore, my analysis confirms the approach of "religious determination" of his practical philosophy. But he also indicates that the intellect has a function in the practical field, namely, that it might contribute to the process of deducing judgments for specific cases from religious principles. But the similarity between this function and the task of fiqh leads me to question whether Avicenna's practical philosophy is encompassed by fiqh.

The easiest way to determine whether he sees practical philosophy as part of fiqh or not is to examine the philosopher's writings on this subject. My examination showed that Avicenna wrote about the practical field in a philosophical method and even appealed to the ideas and concepts of antic philosophers and quoted from their passages. When I investigated why he did so, it became clear that he thinks that their writings might include valuable information because of the supremacy of their souls. I argued that the knowledge acquired from their books might be the source of the moral premises that Avicenna stated in those passages that emphasize the intellect's function in the practical field. Thus, I conclude that his practical philosophy intersects with figh at some point, but that he also considers philosophical knowledge in the practical field. But since divine laws determine practical judgments in the universal and practical base, this approach does not provide a universal, necessary, and independent practical philosophy. Therefore, the difference between this approach and al-Fārābỉ's understanding, which separates philosophical ethics and politics from fiqh, is rather clear.

Finally, I pointed out that the most important factor underlying the difference between their approaches to practical philosophy is their disagreement on the 
relation between religion and philosophy. Even if both philosophers accept that religion has a metaphorical, symbolic, and rhetorical language for explaining reality, they construct the relation between religion and philosophy differently. Al-Fārābī prioritizes philosophy, whereas Avicenna does not qualify philosophy as either prior or determinative. As a result, one understands that religious determination in the practical field is basic, whereas philosophical investigation is only for the space that has not been determined by religion. This investigation intersects with fiqh at some point. But because it does considers both religious sources and antic philosophical sources about the practical field, one cannot say that it is completely encompassed by fiqh.

\section{References}

Alper, Ömer Mahir. İslam Felsefesinde Akıl-Vahiy Felsefe-Din İlişkisi. İstanbul: Ayışığı Kitapları, 2000.

Aydın, Mehmet. “İbn Sînâ’da Ahlâk.” Uluslararası İbn Sina Sempozyumu Bildirileri. Ankara, 1984: 117-31.

"İbn Sînâ'nın Mutluluk (es-Saade) Anlayışı." İbn Sînâ Doğumunun Bininci Yılı Armağanı. Edited by. Aydın Sayılı, 433-51. Ankara: Türk Tarih Kurumu Basımevi, 1984.

Aydınlı, Yaşar. Fârâbî'de Tanrı-İnsan İlişsisi. İstanbul: İz Yayıncılık, 2000.

Bircan, Hasan Hüseyin. "Fârâbînnin İlimler Tasnifi Bağlamında Siyaset ve Ahlâkın Neliği." İslâmiyât VI, no. 4 (2003): 139-50.

Black, Deborah L. "Practical Wisdom, Moral Virtue and Theoretical Knowledge: The Problem of the Autonomy of the Practical Realm in Arabic Philosophy." Moral and Political Philosophies in the Middle Ages. Edited by B. Carlos Bazan et al., 451-65. Ottova: Legas, 1995.

Butterworth, Charles. "Medieval Islamic Philosophy and the Virtues of Ethics." Arabica 34 (1987): 221-50.

"Ahlak ve Siyaset Felsefesi." İslam Felsefesine Giriş. Edited by P. Adamson and R. C. Taylor. Translated by Cüneyt Kaya, 293-315. İstanbul: Küre Yayınları, 2007.

"Ethics in Medieval Islamic Philosophy." The Journal of Religious Ethics 11, no. 2 (1983): 224-39.

“The Political Teaching of Avicenna." Topoi 19 (2000): 35-44.

De Boer, T. J. İslām'da Felsefe Tarihi. Translated by Y. Kutluay. İstanbul: İnkılap Yayınları, 2004.

Druart, Thérèsè-Anne. "Al- Fārābī on the Practical and Speculative Aspects of Ethics." Moral and Political Philosophies in the Middle Ages. Edited by B. Carlos Bazan et al., 476-85. Ottova: Legas, 1995.

, “Al-Fārābī, Ethics and First Intelligibles.” Documents Etudi Sulla Tradizione Filozofica Medieval VIII (1997): 403-23.

Endress, Gerhard (ed.), Organizing Knowledge: Encyclopaedic Activities in the Pre-Eighteenth Century Islamic World. Leiden: Brill, 2006.

Fahri, Macit. İslam Ahlâk Teorileri. Translated by Muammer İskenderoğlu, Atilla Arkan. İstanbul: Litera Yayınları, 2004.

al-Fārābī. Fusūl muntaza'a, Edited by Fawzi Mitri Najjār. Beirut: Dār al-Mashriq, 1986. Ihṣāa al-'ulūm, Edited by Ali Bū Mülhim. Beirut: Dār wa Maktaba al-Hilāl, 1996. Kitāb Ārā' ahl al-madīna al-fāḍila, Edited by Albert Nāsrī Nādir. Beirut: Dār al-Mashriq, 1985. 
, Kitāb Tahṣīl al-sa 'āda. Edited by Cafer Āl-i Yãsīn. Beirut: Dār al-Andalus, 1983.

, Kitāb al-Khurūf, Translated by Ömer Türker. İstanbul: Litera Yayıncılık, 2008.

, Kitāb al-Milla. Edited by Muhsin Mahdī. Beirut: Dār al-Mashriq, 1968.

, Kitāb al-Siyāsa al-madaniyya. Edited by Fawzi Mitrī Najjār. Beirut: Dār al-Mashriq, 1993.

Risāla al-tanbīh 'alā sabīl al-sa'āda. Edited by Sahban Khalīāt. Amman: al-Jāmia Urdūniyya, 1987.

Galston, Miriam. “Realism and Idealism in Avicenna's Political Philosophy." The Review of Politics 40, no. 4 (October 1979): 561-77.

Ghazzālī. al-Mostașfā min 'ilm al-uṣūl. Edited by Mohammad Soleiman al-Ashkar. Beirut: Muassasa al-Risāla, 1997.

Gutas, Dimitri. "Paul the Persian on the Classification of the Parts of Aristotle's Philosophy: A Milestone between Alexandria and Bagdad." Der Islam 60, no. 2 (1983): 231-67.

“The Meaning of madanī in al-Farabi's 'Political' Philosophy." Mélanges de l’Université Saint-Joseph 57 (2004): 259-82.

"The Heritage of Avicenna: The Golden Age of Arabic Philosophy, 1000-ca. 1350." Avicenna and His Heritage. Edited by Jules L. Janssens and Daniel De Smet, 81-97. Leuven: Leuven University Press, 2002.

"The study of Arabic philosophy in the twentieth century: An essay on the historiography of Arabic philosophy." British Journal of Middle Eastern Studies 29, no. 1 (2002): 19-25.

Avicenna and the Aristotelian Tradition. Boston: Brill, 2014.

Ibn Sīnā. al-Mubāhathāt. Edited by Muhsin Bidarfar. Qum: Muasssaa-i Pejūheshha-1 Hikma wa Falsafa-i Irān, $1371 \mathrm{AH}$.

, 'Uyūnu al-hịkma. Edited by Abdurrahman Badawī. Beirut: Dār al-Qalam, 1980.

“al-Birr wa al-ithm." al-Mazhab at-tarbawī 'inda Ibn Sīnā. Edited by Abdulamr Shamsaddin, 353-68. Beirut: al-Sharika al-Ālamiyya li al-kitāb, 1988.

, "Risāla fī aqsām al-'ulūm al-'aqliyya.” Edited by Halide Yenen. “İbn Sînâ'da İlimler Tasnifi ve Risâle fî Aksâm el-Hikme,” Kutadgubilig 14 (2008): 59-95.

"Risāla fī Siyāsa al-manziliyya." al-Mazhab at-tarbawī 'inda Ibn Sīnā. Edited by Abdulamr Shamsaddin, 232-60. Beirut: al-Sharika al-'Ālamiyya li al-kitāb, 1988.

"Risāla fī al-kalām 'alā al-nafs al-nāṭqa." Aḥwāl an-nafs. Edited by Aḥmad Fu'ād el-Ahvānī, 195-199. Cairo: 'Īsā al-Bābi al-Ḥalabī, 1952.

, Aḥwāl al-nafs. Edited by Aḥmad Fu'ād el-Ahvānī. Cairo: 'Īsā al-Bābi al-Ḥalabī, 1952.

Dāneshnāme-i Ālāĩ: Alāī Hikmet Kitabı. Translated by Murat Demirkol. İstanbul: Türkiye Yazma Eserler Kurumu Bashkanlığı Yayınları, 2013.

, al-Ishārāt wa al-tanbīhāt II. Edited by Sulaiman Dunyā. Cairo, 1985.

, al-Shifä'/al-Manțiq I: al-Madkhal. Edited by Fu'ād el-Ehvānī et al. Cairo, 1952.

, al-Shifä'al-Manțiq VIII: al-Khatāba. Edited by Ibrahim Madkūr. Cairo: al-Mațba'a al-Āmiriyya, 1954.

, (Kitāb al-Shifä':) Metafizik, II. Translated by Ekrem Demirli and Ömer Türker. İstanbul: Litera Yayınları, 2005.

Mantiq al-mashriqiyyīn. Qum: Maktaba Āyetullah al-Uzmā An-Najafī al-Mar’ashī, 1405.

Janssens, Jules L. "Al-Birr wa'l-ithm, Piety and Sin: Possible Farabian Influences on the Young Ibn Sina." Ishraq: Islamic Philosophy Yearbook III (2012): 412-22.

“Experience' (tajriba) in Classical Arabic Philosophy (al-Farabi-Avicenna)." Quaestio 4 (2004): 45-62. 
"Ibn Sīnā (Avicenna): un projet 'religieux' de philosophie?" Was ist Philosophie im Mittelalter? Edited by J. A. Aertsen and A. Speer, 863-70. Berlin \& New York: Walter de Gruyter, 1998.

Kaya, M. Cüneyt. "Peygamberin Yasa Koyuculuğu: İbn Sînâ’nın Amelî Felsefe Tasavvuruna Bir Giriş Denemesi.” Dîvân: Disiplinlerarası Çalışmalar Dergisi 27 (2009): 57-91.

"In the Shadow of 'Prophetic Legislation': The Venture of Practical Philosophy after Avicenna." Arabic Sciences and Philosophy 24 (2014): 269-96.

"Prophetic Legislation: Avicenna's View of Practical Philosophy Revisited." Philosophy and the Abrahamic Religions: Scriptural Hermeneutics and Epistemology. Edited by Torrance Kirby et al., 205-23. Newcastle: Cambridge Scholar Publishing, 2013.

Kutluer, İlhan. "İslam Felsefesi Tarihinde Ahlāk İlminin Teshekkülü.” Unpublished PhD diss., Marmara University. İstanbul, 1989.

Leaman, Oliver. "Does the interpretation of Islamic philosophy rest on a mistake?" International Journal of Middle East Studies 12 (1980): 525-38.

Legenhausen, Hajj Muhammad. “Ibn Sina's Practical Philosophy.” Religious Inquiries 2, no. 3 (2013): 5-27.

Mahdi, Muhsin S. Alfarabi and the Foundation of Islamic Political Philosophy. Chicago: The University of Chicago Press, 2010.

“Avicenna: Practical Science." Encyclopedia Iranica, III, 84-88.

Mansureh, Bakhshi et al. "Place of Woman in Social System and Family from the Point of View of Farabi, Avicenna and Khadej Nasir." Avicinian Philosophy Journal 22, no. 59 (2018): 5-25.

Marmura, M. E. “Al-Ghazali on Ethical Premises.” The Philosophical Forum 1, no. 3 (1969): 393-403.

Morris, James W. “The Philosopher-Prophet in Avicenna's Political Philosophy.” The Political Aspects of Islamic Philosophy, ed. Charles E. Butterworth, 153-98. Cambridge, 1992.

Murad, Ali Abbas. Davla al-sharīa: Qırāa fí jadaliyya al-dīn wa al-siyāsa 'inda Ibn Sīnā. Beirut, 1999.

Nadia, Maftouni and Noori Mahmoud. "A Comparative Study on Farabi and Avicenna's Viewpoints About the Ultimate Goal of Art and the Role of Entertainment, Wonder and Pleasure." Avicinian Philosophy Journal 22, no. 59 (2018): 27-40.

Özturan, Hümeyra. Akıl ve Ahlāk: Aristoteles ve Fārābī'de Ahlakın Kaynağı. İstanbul: Klasik Yayınları, 2014.

Rosenthal, Erwin I. J. "Ibn Sīnā: The Synthesis." Political Thought in Medieval Islam: An Introductory Outline. Edited by Erwin I. J. Rosenthal, 143-57. Cambridge, 1958.

Saruhan, Müfit Selim. “İbn Sīnā’da Ahlākī Çözüm Üzerine.” Uluslararası İbn Sīnā Sempozyumu Bildirileri. Edited by M. Mazak and N. Özkaya, 121-35. İstanbul: İstanbul Büyükshehir Belediyesi Kültür A.ş., 2009.

Schramm, Matthias. "Theoretische und Praktische Disziplin bei al-Fārābī." Zeitschrift für Geschichte der arabisch-islamischen Wissenchaften 3 (1986): 1-55.

Shāfiī. al-Risāla. Edited by Aḥmad Muhammed Shaqīr. Cairo: Mațba‘a Mușțafā 'Īsā al-Bābi al-Ḥalabī, 1938.

Risale. Translated by Abdülkadir Şener ve İbrahim Çalışkan. Ankara: TDV Yayınları, 2007.

Şahinoğlu, Şeyma. “İbn Sînâ’da Ahlâk Sorunu.” Unpublished MA diss., Marmara University. 2009.

Toktaş, Fatih. “İbn Sînâ’nın “Risâle Fî 'İlmi'l-ahlâk” Risalesinin Takdim, Tahkik ve Çevirisi.” DEUİFD XLIII (2016): 7-52.

Türker, Ömer. “İslam Düşüncesinde İlimler Tasnifi.” Sosyoloji Dergisi III, no. 22 (2011): 533-56. 